\title{
Impacts of Bank Competition, Financial Stability, and Gender Gap on Access to Finance: Evidence From Sub-Saharan Africa
}

Bijoy Rakshit ( $\nabla$ bijoy.rakshit@iitrpr.ac.in )

Indian Institute of Technology Ropar

Research

Keywords: Bank Competition, Financial Stability, Sub-Saharan Africa

Posted Date: February 18th, 2021

DOl: https://doi.org/10.21203/rs.3.rs-210421/v1

License: (c) (1) This work is licensed under a Creative Commons Attribution 4.0 International License.

Read Full License 


\section{Abstract}

Using a dataset of 12504 firms from World Bank Enterprise Survey (WBES), this paper investigates the role of bank competition, financial stability and gender gap in access to finance in Sub-Saharan Africa. We empirically test the existence of market power hypothesis according to which pro-competitive policies alleviate credit constraints from the banking industry. Results obtained through probit model and probit model of sample selection (PSS) confirm that a higher degree of market power negatively affected firm financing in the region. Findings further reveal that the lower rate of female ownership partnerships creates difficulties in obtaining formal finance for female entrepreneurs. Financial stability does not affect access to finance in SSA as indicated by the estimation results. We discuss several policy implications for the region.

JEL Classification: D22 . G20 . L11

\section{Introduction}

Limited access to finance is considered a major challenge to economic growth both in developed and emerging economies (Demirguc-Kunt et al. 2008). It is argued that a deep banking system can limit access to credit if it lacks competition, serves only incumbent firms and operates without regard to prudential regulations. While extant literature documents the implications of bank competition in promoting economic growth (Aluko and Ajayi 2018; Cherif et al. 2020; Sarpong-Kumankoma et al. 2020), adequate attention has not been paid on the implications of bank competition and financial stability in firm's financing constraint. Financial liberalizations in the 1990s, the boom in commodity prices, and economic growth have contributed significantly to the expanding banking sector in Sub-Saharan Africa (SSA) (Mlachila et al. 2013; Otchere et al. 2017). Despite the realized merits of bank competition, the structure of markets is often characterized by anti-competitive practices and regulations. The widespread presence of state-owned banks, the greater degree of monopoly and holding the largest market share by single operators are the key elements that affected the banking competitiveness in the region. Even though a decrease in competition and rising corporate market power has gained notable attention in emerging economies (IMF 2019a; De Loecker et al. 2020), a systematic analysis in the pattern and variation of bank competition in SSA remained unexplored. Based on the sample of selected SSA countries, Cherif et al. (2020) show that in general, bank competition in SSA remains low compared to the rest of the world.

In addition to low bank competition, SSA region is also grappled with the problem of financial stability. In the face of the Nigerian banking crisis of 2009-10, increased protectionism, stricter regulations in global financial conditions, and external pressures including the threat of de-risking have raised concern over financial stability in the region. Previous studies mostly focus on the effects of financial inclusion on financial stability, ignoring the likely possibility of the role of stability in channelizing access to finance to firms. Considering the fact that a competitive banking system may not necessarily stable (Berger et al. 
2017), this study attempts to examine the joint impact of competition and stability on firms' credit availability.

Another less debated aspect in the discussion of access to finance is the potential gender gap. It is argued that lack of access to finance to female-led business enterprises impedes female entrepreneurship and discourages female participation in the modern financial market. With less than one in five households having access to finance, this problem is much stressing in SSA than in other developing countries (Honohan and Beck 2007). World Bank data shows the SSA region is characterized by a higher degree of gender discrimination measured by Women, Business and the Law index as compared to other countries in the world. The values of the index are substantially lower in SSA that the rest regions. It indicates that the average index value in SSA is 0.5 and 0.85 for the rest countries. Smaller values indicate higher gender discrimination; it can be inferred that the region's business and legal environment is characterized by a higher degree of the gender gap.

Given the background, this study seeks to address the following research questions. First, does an increase in bank competition enhance or hindrance access to formal finance in SSA region? Second, whether ensuring financial stability improves firm's financing. What is the joint effect of bank competition and financial stability on credit availability? Third, does gender discrimination affect the probability of credit constraint for female-led enterprises?

This study contributes to the existing literature on firm financing in the following ways. Using firm-level data from Word Bank Enterprises Survey (WBES) and bank-level information, this study investigates the role of competition, financial stability, and the gender gap in selected SSA. While most studies on access to finance are limited to developed and emerging economies, this study is the first of its kind that explores the association between market power and credit availability in SSA. Aterido et al. (2013) considered the role of the gender gap in analyzing access to finance, however, the implication of bank competition and financial was not addressed in their study. Since existing studies revolve around two competing hypotheses viz., market power hypothesis and information hypothesis to examine the implication of bank competition on access to finance, this study tests the existence of these two hypotheses in the context of SSA region. Based on the income level, we further analyzed the variations in firm's credit status across the countries in the region. Finally, we apply both direct and indirect measures of access to finance, several firm-specific, country-specific, macroeconomic, and institutional variables in this study.

\section{Methodology And Data}

First, we measure bank competition and financial stability by Lerner index, Boone indicator and Z-score. Lerner index is formally defined as the relative difference between price and marginal cost divided by the price and corresponds to the inverse of the price elasticity of demand. Lerner index (1934) can be measured as follows. 
Lerner $=\frac{P_{i, t}-M C_{i, t}}{P_{i, t}}$.

where $\mathrm{P}_{\mathrm{i}, \mathrm{t}}$ denotes the price of bank $i$ at time t. $\mathrm{MC}$ denotes the marginal cost of banks and $\mathrm{e}$ is the elasticity of demand. The value of the Lerner index lies from a maximum value of one to the minimum value of zero.

Boone (2008) defines market power as an estimate of the percentage decrease in profits resulting from one per cent increase in marginal cost. Boone indicator for bank $i$ at time $t$ can be defined

\section{Profit elasticity $=\frac{\partial \ln \pi_{i}}{\partial \ln m c_{i}}$}

The inverse relationship between profit and marginal cost suggests the profit elasticity to be negative. The stronger the effect, the more negative value of Boone indicator is.

Z-score measures the probability of default of the banking system. Following Cihak and Hesse (2010), we estimate the Z-score as

$$
Z-\text { score }_{i}=\frac{R O A_{i}+\frac{E_{i}}{T A_{i}}}{\sigma R O A} .
$$

Where ROA denotes return on assets calculated by bank's net income divided by total assets. E/TA is the equity to total assets, and $\sigma R O A$ is the standard deviation of the return on assets. A higher index of Zscore implies that banks are relatively more stable and have a lower probability of being

insolvent and vice versa. We use three years rolling window to estimate the standard deviation.

After estimating bank competition and stability indicator, following Aterido et al. (2013), we specify the following regression equation, where our interest of variables are measured at the level of firm $i$ in country $c$ at time $t$

$$
\begin{aligned}
& y_{i c t}=\beta_{0}+\beta_{1} \text { competition }_{i c t}+\beta_{2} \text { stability }_{i c t}+\beta_{3} \text { Gender }_{i c t}+\gamma F S_{i c t}+\text { econtrols }_{c t}+ \\
& \delta M_{c t}+\epsilon_{i c t}
\end{aligned}
$$

The dependent variable is a dummy variable $y$ that takes a value of 1 if a firm has access to a bank loan or overdraft facility, or 0 otherwise. To capture the role of gender, we first consider the participation of female ownership and assign a dummy variable 1, indicating at least one principal owner is female. We also consider the gender of the manager and assign a dummy variable one if the manager is female. FS 
that denotes firm-specific characteristics includes the size of the firms by the number of permanent fulltime employees. We consider three types of firms, namely small firms (6 to 10 employees), medium firms (11 to 49 employees) and large firms (50 or more employees). Experience is defined by the experience of the top managers in years. Additionally, we consider the age, ownerships and sector of the firms (manufacturing and service firms only). To get rid of the omitted variable bias, we take into account a set of control variables such as bank branch, financial freedom and macroeconomic variables, namely GDP growth and inflation rate. Survey fixed effects are denoted by M. Survey fixed effects are crucial to control for the potential shocks or measurement errors across different country years, where the surveys are conducted. Our sample includes 40 SSA countries covering 12504 formal firms during the period 2009 to 2019 (Table 2a). We estimate equation (4) with probit model and PSS.

\section{Empirical Results}

Table 1 presents the descriptive statistics of the variables. It shows that 67.40 per cent of total firms in our sample have access to finance. Considering the alternative indicator, we report that 84.5 per cent of firms face credit constraints. This implies that on average, 84.4 per cent of total firms despite having a formal credit need did not apply for a formal bank credit due to various reasons. The maximum value of the Lerner index (49.5) indicates the existence of higher market power and less bank competition in the region. With regards to the gender of the owners, we find that only 12.1 per cent managers are female, and 23.1 per cent of firms have at least one female owner. The mean value of the size variable suggests that most firms are medium-sized.

\section{Table 1: Summary statistics}




\begin{tabular}{|llllll|}
\hline Variables & Obs & Mean & SD & Minimum & Maximum \\
\hline Access to finance & 12504 & 0.674 & 0.421 & 0 & 1 \\
\hline Credit constraint & 12504 & 0.845 & 0.457 & 0 & 1 \\
\hline Lerner Index & 12504 & 0.315 & 0.094 & 0.113 & 0.495 \\
\hline Boone Indicator & 12504 & -0.0789 & 0.112 & -0.654 & 0.204 \\
\hline Z-score & 12504 & 8.954 & 0.354 & 2.54 & 19.654 \\
\hline Bank Branches & 40 & 2.431 & 0.089 & 1.914 & 7.571 \\
\hline Female ownership & 12504 & 0.231 & 0.451 & 0 & 1 \\
\hline Female manager & 12504 & 0.121 & 0.341 & 0 & 1 \\
\hline Size & 12504 & 42.17 & 456.32 & 1 & 27,547 \\
\hline Age & 12504 & 16.54 & 14.561 & 1 & 117 \\
\hline Experience & 12504 & 19.27 & 11.524 & 1 & 97 \\
\hline Government & 12504 & 0.024 & 0.1337 & 0 & 1 \\
\hline Private & 12504 & 0.831 & 0.3731 & 0 & 1 \\
\hline Manufacturing & 12504 & 0.645 & 0.345 & 0 & 1 \\
\hline
\end{tabular}

Source: Authors calculations

Models 1, 2, 3 and 4 in table 2 show that Lerner index has a negative and significant impact on access to finance. One per cent increase in market power causes access to finance to fall by 3.7, 2.9, 4.4, and 4.1 per cent respectively across all the estimated models. Higher interest rates charged on loans due to the banking industry's growing monopoly significantly reduce credit availability. In other words, bank competition has the potential to improve the access the finance by considering the low-interest policy. The finding lends support to market power hypothesis and is in line with Leon (2015) and Ayalew and Xianzhi (2019). Though we do not find any significant impact of financial stability on access to finance, the coefficient of the interaction term between the Lerner index and Z-score has been found positive and significant across all the models. This allows us to infer that a stable and competitive banking industry helps improve access to finance in the region

Less participation of females in business enterprises makes it difficult for female-led entrepreneurs to receive formal credit. This finding has been confirmed by the negative and significant coefficient of female ownership in all the estimated models. However, we fail to draw any inference about the role of the female manager in obtaining firm finance. Though the coefficient sign is negative as expected, lack of significance level restricts us to derive definitive implications of whether female managers face difficulties in obtaining finance. The findings further reveal that small and medium-sized firms face 
greater credit constraints compared to their large counterparts. Privately-owned firms have greater credit constraints than government firms. The significant coefficients of bank branches suggest that the widespread presence of bank branches per 100,000 adults is likely to increase access to finance. With regards to the macroeconomic and institutional factors, we find consistent results in line with the economic intuitions.

Table 2: Dependent variable: Access to finance 


\begin{tabular}{|c|c|c|c|c|}
\hline & Model 1 & Model 2 & Model3 & Model 4 \\
\hline \multirow[t]{2}{*}{ Lerner index } & $-0.037 \star \star \star$ & $-0.029 \star \star \star$ & $-0.044^{\star \star \star}$ & $-0.041 * \star \star$ \\
\hline & $(0.0017)$ & $(0.0092)$ & $(0.0847)$ & $(0.0715)$ \\
\hline \multirow[t]{2}{*}{ Z-score } & 0.0001 & 0.0014 & 0.0003 & 0.002 \\
\hline & $(0.0022)$ & $(0.0047)$ & $(0.0725)$ & $(0.0561)$ \\
\hline \multirow[t]{2}{*}{ Lerner*Z-score } & $0.047 \star \star \star *$ & $0.032^{\star \star \star}$ & $0.044 * \star \star$ & $0.043 * \star \star *$ \\
\hline & $(0.3547)$ & $(0.4875)$ & $(0.7754)$ & $(0.6457)$ \\
\hline \multirow[t]{2}{*}{ Bank Branches } & $0.847 \star \star \star$ & $0.829 * \star \star$ & $0.764 * \star \star$ & $0.567 \star \star \star$ \\
\hline & $(0.0044)$ & $(0.0037)$ & $(0.0021)$ & $(0.0032)$ \\
\hline \multirow[t]{2}{*}{ Female ownership } & 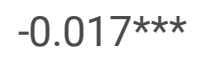 & $-0.018^{\star \star \star}$ & $-0.014 * \star \star$ & $-0.015^{\star \star \star}$ \\
\hline & $(0.0016)$ & $(0.0224)$ & $(0.0146)$ & $(0.01374)$ \\
\hline \multirow[t]{2}{*}{ Female manager } & -0.0574 & -0.0417 & -0.032 & -0.054 \\
\hline & $(0.0055)$ & $(0.0057)$ & $(0.0067)$ & $(0.0054)$ \\
\hline \multirow[t]{2}{*}{ Small firms } & & $-0.241 \star \star \star$ & 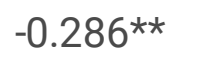 & $-0.264^{\star \star \star}$ \\
\hline & & $(0.0257)$ & $(0.0551)$ & $(0.0457)$ \\
\hline \multirow[t]{2}{*}{ Medium firms } & & $-0.007 * \star \star$ & $-0.004^{*}$ & $-0.004^{\star \star}$ \\
\hline & & $(0.0087)$ & $(0.0047)$ & $(0.0039)$ \\
\hline \multirow[t]{2}{*}{ Large firms } & & -0.243 & -0.248 & -0.276 \\
\hline & & $(0.8874)$ & $(0.7314)$ & $(0.8974)$ \\
\hline \multirow[t]{2}{*}{ Age of firms } & & & $0.006 * \star \star$ & $0.005^{\star \star \star}$ \\
\hline & & & $(0.0035)$ & $(0.0025)$ \\
\hline \multirow[t]{2}{*}{ Experience } & & & 0.0018 & 0.054 \\
\hline & & & $(0.0036)$ & $(0.096)$ \\
\hline \multirow[t]{2}{*}{ Manufacturing } & & & $-0.024^{\star \star}$ & $-0.028 * \star \star *$ \\
\hline & & & $(0.0547)$ & $(0.0247)$ \\
\hline \multirow[t]{2}{*}{ Private ownership } & & & $-0.003^{*}$ & $-0.024^{\star \star}$ \\
\hline & & & $(0.0124)$ & $(0.0798)$ \\
\hline \multirow[t]{2}{*}{ Government ownership } & & & 0.021 & 0.022 \\
\hline & & & $(0.0023)$ & $(0.0214)$ \\
\hline Inflation & & & 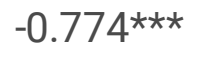 & $-0.524 * \star \star$ \\
\hline
\end{tabular}




\begin{tabular}{|c|c|c|c|c|}
\hline & & & $(0.8254)$ & $(0.8952)$ \\
\hline Economic growth & & & & $0.224^{\star \star \star}$ \\
\hline & & & & \\
\hline \multirow[t]{2}{*}{ Financial freedom } & & & & $0.004^{\star * *}$ \\
\hline & & & & $(0.0007)$ \\
\hline Industry fe & yes & yes & yes & yes \\
\hline Survey fe & yes & yes & yes & yes \\
\hline Observations & 12504 & 12504 & 12504 & 12504 \\
\hline Psedu-Rsq & 0.34 & 0.33 & 0.31 & 0.27 \\
\hline
\end{tabular}

Note: Models are calculated with probit regressions. We report standard errors in the parentheses

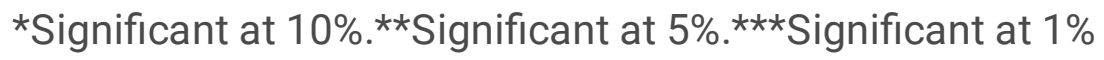
Table 3: Dependent variable: Credit constraint (Robustness Test) 


\begin{tabular}{|c|c|c|c|c|}
\hline & Model 1 & Model 2 & Model 3 & Model-4 \\
\hline \multirow[t]{2}{*}{ Boone Indicator } & $0.026 * \star \star$ & $0.025^{\star \star \star}$ & 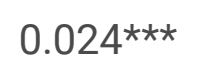 & $0.025^{\star \star \star}$ \\
\hline & $(0.0018)$ & $(0.0025)$ & $(0.0102)$ & $(0.0827)$ \\
\hline \multirow[t]{2}{*}{ Z-score } & 0.006 & 0.002 & 0.004 & 0.0010 \\
\hline & $(0.0041)$ & $(0.0034)$ & $(0.003)$ & $(0.0061)$ \\
\hline \multirow[t]{2}{*}{ Boone*Z-score } & $-0.024 * \star \star$ & $-0.025^{\star \star \star}$ & $-0.013^{\star \star \star}$ & $-0.289 * \star \star$ \\
\hline & $(0.2451)$ & $(0.0331)$ & $(0.0491)$ & $(0.0028)$ \\
\hline \multirow[t]{2}{*}{ Bank Branches } & -0.085 & -0.103 & -0.115 & 0.132 \\
\hline & $(0.0247)$ & $(0.0451)$ & $(0.0244)$ & $(0.0947)$ \\
\hline \multirow[t]{2}{*}{ Female ownership } & 0.020 & $0.033^{* *}$ & $0.059 \star \star \star$ & $0.009 * * *$ \\
\hline & $(0.2244)$ & $(0.1874)$ & $(0.1574)$ & $(0.0147)$ \\
\hline \multirow[t]{2}{*}{ Female manager } & -0.005 & -0.001 & -0.002 & -0.002 \\
\hline & $(0.0143)$ & $(0.0271)$ & $(0.0017)$ & $(0.0029)$ \\
\hline \multirow[t]{2}{*}{ Small firms } & & $0.051^{\star \star \star}$ & 0.057 & 0.023 \\
\hline & & $(0.0071)$ & $(0.0487)$ & $(0.0089)$ \\
\hline \multirow[t]{2}{*}{ Medium firms } & & $0.497^{*}$ & $0.336^{*}$ & $0.471^{*}$ \\
\hline & & $(0.0854)$ & $(0.2147)$ & $(0.0251)$ \\
\hline \multirow[t]{2}{*}{ Large firms } & & & 0.487 & 0.521 \\
\hline & & & $(0.2254)$ & $(0.0012)$ \\
\hline \multirow[t]{2}{*}{ Age of firms } & & & 0.024 & -0.031 \\
\hline & & & $(0.0027)$ & $(0.0021)$ \\
\hline \multirow[t]{2}{*}{ Experience } & & & $-0.774^{\star \star \star}$ & -0.874 * \\
\hline & & & $(0.4578)$ & $(0.9847)$ \\
\hline \multirow[t]{2}{*}{ Manufacturing } & & & $0.357 * \star \star$ & $0.367 * \star \star *$ \\
\hline & & & $(0.0147)$ & $(0.0214)$ \\
\hline \multirow[t]{2}{*}{ Private ownership } & & & $0.005^{\star \star}$ & $0.007^{\star}$ \\
\hline & & & $(0.0214)$ & $(0.0578)$ \\
\hline \multirow[t]{2}{*}{ Government Ownership } & & & 0.134 & 0.148 \\
\hline & & & $(0.0745)$ & $(0.0445)$ \\
\hline Inflation & & & $0.014 * \star$ & $0.015^{\star \star \star}$ \\
\hline
\end{tabular}




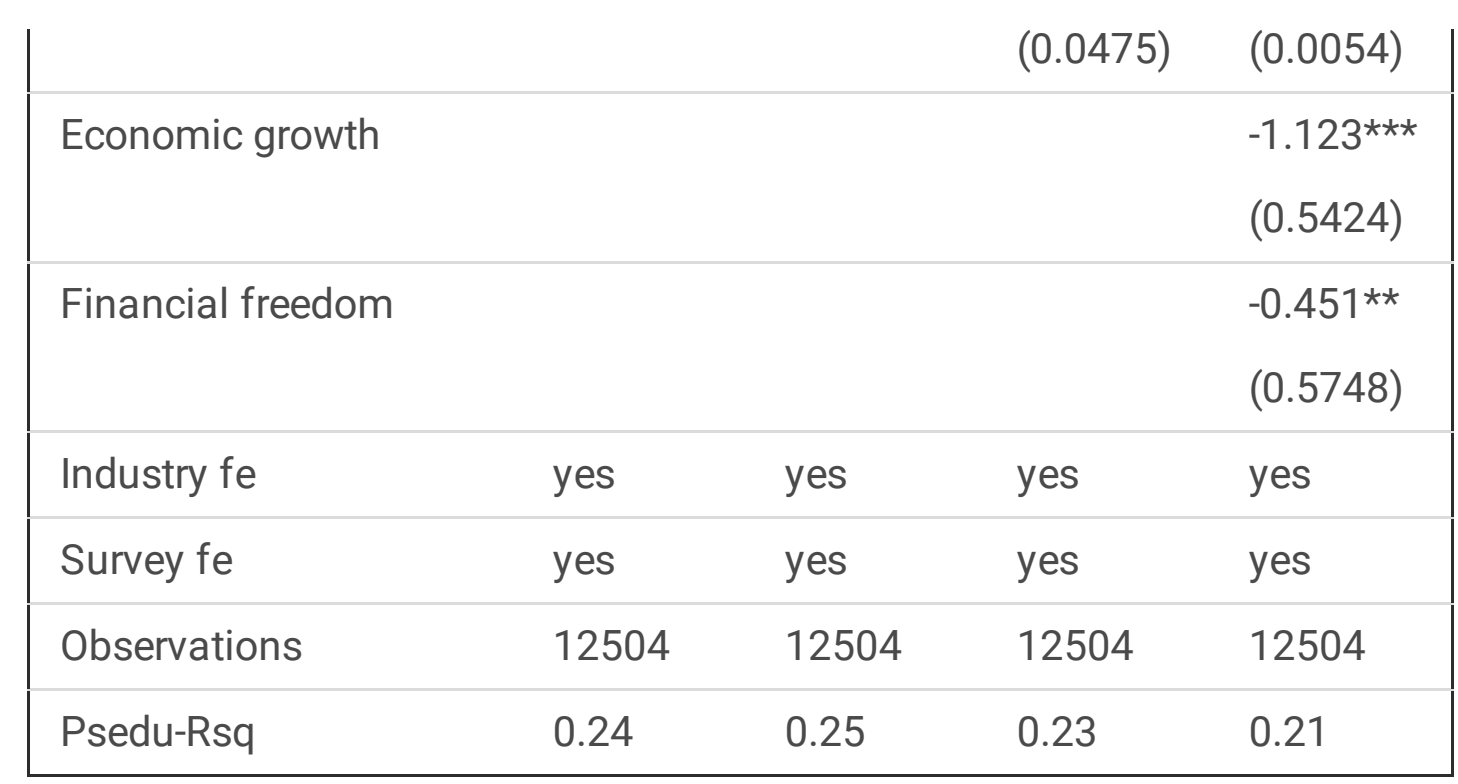

Note: Models are calculated with probit model with sample selection (PSS) regressions. We report standard errors in the parentheses

*Significant at $10 \% . \star *$ Significant at $5 \% . * \star \star$ Significant at $1 \%$

\section{Robustness Test}

To see the extent to which our main findings are consistent, we check the robustness of the main estimation results. To do so, we replace the dependent variable with an alternative indicator, i.e. credit constraint. This measure is only relevant only for the firms with a need for bank credit. Therefore, we control for the possibility of sample selection bias by applying the probit model with sample selection (PSS). While performing the robustness test, we use the Boone indicator instead of the Lerner index as a measure of bank competition. Table 3 presents the results of the robustness. Table 3 shows that Boone indicator, a direct measure of market power exerts a positive and significant impact on credit constraint, implying that market power gives rise to credit constraint in the SSA region. Similarly, we find that female ownership participation has a positive and significant impact on credit constraint. The economic implications of the negative findings can be attributed to the weak credit information system in SSA. Lack of credit information may create informational asymmetries in the credit market, leading to adverse selection and moral hazard problems, which makes external finance less affordable to the borrowers.

Finally, we examine the impact of bank competition, financial stability and gender role on access to finance among the low income, lower middle income and upper-middle-income countries. The results have been presented in table 4 . We group our total sample countries into the three income groups. We find that higher market power invariably affects firms financing across three groups. However, unlike upper middle income, female ownership participation adversely affects access to finance in lower and lower middle income countries of SSA. Lastly, we find that small and medium-sized firms face greater financing obstacles in lower and lower middle income countries. 


\begin{tabular}{|c|c|c|c|}
\hline & Lower-income & Lower middle income & Upper middle income \\
\hline \multirow[t]{2}{*}{ Lerner index } & $-0.187 \star \star \star$ & $-0.2945^{\star \star \star}$ & $-0.1478^{\star \star \star}$ \\
\hline & $(0.2317)$ & $(0.2541)$ & $(0.4712)$ \\
\hline \multirow[t]{2}{*}{ Z-score } & 0.021 & 0.014 & 0.074 \\
\hline & $(0.1147)$ & $(0.1247)$ & $(0.1047)$ \\
\hline \multirow[t]{2}{*}{ Boone*Z-score } & $0.041^{\star \star \star}$ & $0.037 * \star \star$ & 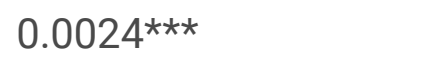 \\
\hline & $(0.0021)$ & $(0.0047)$ & $(0.0041)$ \\
\hline \multirow[t]{2}{*}{ Bank Branches } & $0.025^{\star \star \star}$ & $0.092^{\star \star \star}$ & $0.098 * \star \star$ \\
\hline & $(0.0241)$ & $(0.0034)$ & $(0.0514)$ \\
\hline \multirow[t]{2}{*}{ Female ownership } & $-0.018 \star \star$ & $-0.0251 * \star$ & -0.048 \\
\hline & $(0.1133)$ & $(0.1632)$ & $(0.1461)$ \\
\hline \multirow[t]{2}{*}{ Female manager } & -0.011 & -0.009 & -0.002 \\
\hline & $(0.0071)$ & $(0.0145)$ & $(0.0214)$ \\
\hline \multirow[t]{2}{*}{ Small firms } & $-0.043^{\star \star \star}$ & $-0.055^{\star \star \star}$ & -0.012 \\
\hline & $(0.0089)$ & $(0.0061)$ & $(0.0314)$ \\
\hline \multirow[t]{2}{*}{ Medium firms } & $-0.214^{\star \star \star}$ & $-0.321^{\star \star \star}$ & $-0.225^{\star \star \star}$ \\
\hline & $(0.5114)$ & $(0.0732)$ & $(0.0514)$ \\
\hline \multirow[t]{2}{*}{ Large firms } & 0.471 & 0.475 & 0.487 \\
\hline & $(0.0587)$ & $(0.6641)$ & $(0.2254)$ \\
\hline \multirow[t]{2}{*}{ Age of firms } & $0.021^{\star \star \star}$ & 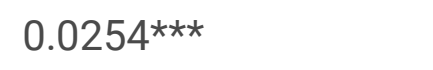 & $0.024^{\star \star \star}$ \\
\hline & $(0.1247)$ & $(0.0018)$ & $(0.0027)$ \\
\hline \multirow[t]{2}{*}{ Experience } & $0.264 * \star \star$ & 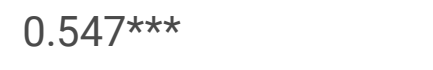 & $-0.774^{\star \star \star}$ \\
\hline & $(0.1514)$ & $(0.2748)$ & $(0.4578)$ \\
\hline \multirow[t]{2}{*}{ Manufacturing } & $0.324 * \star$ & $0.331 * \star \star$ & $0.357 * \star \star$ \\
\hline & $(0.2147)$ & $(0.1742)$ & $(0.0147)$ \\
\hline \multirow[t]{2}{*}{ Private ownership } & $0.003^{*}$ & $0.004^{\star \star \star}$ & $0.005^{\star \star}$ \\
\hline & $(0.0121)$ & $(0.0261)$ & $(0.0214)$ \\
\hline \multirow[t]{2}{*}{ Government Ownership } & $0.124 * \star$ & $0.154^{\star \star \star}$ & $0.134^{\star \star \star}$ \\
\hline & $(0.4121)$ & $(0.0841)$ & $(0.0745)$ \\
\hline Inflation & $0.011^{\star \star}$ & 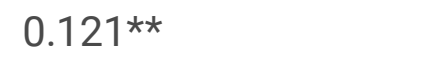 & $0.014 * \star$ \\
\hline
\end{tabular}




\begin{tabular}{|llll|} 
& $(0.0154)$ & $(0.0144)$ & $(0.0475)$ \\
\hline Economic growth & $0.0811^{\star \star *}$ & $0.091^{\star \star *}$ & 0.074 \\
& $(0.1452)$ & $(0.2145)$ & $(0.2141)$ \\
\hline Financial freedom & $0.012^{\star \star}$ & 0.012 & $0.0121^{\star \star}$ \\
& $(0.0024)$ & $(0.0012)$ & $(0.2114)$ \\
\hline Industry fe & yes & yes & yes \\
\hline Survey fe & yes & yes & yes \\
\hline Observations & 12504 & 12504 & 12504 \\
\hline Psedu-Rsq & 0.54 & 0.45 & 0.39 \\
\hline
\end{tabular}

Note: Models are calculated with probit regressions. We report standard errors in the parentheses

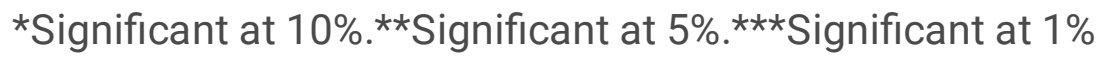

\section{Conclusion And Policy Implications}

This study concludes that a higher degree of market power in the SSA region has adversely affected access to finance, supporting the market power hypothesis. Findings do not extend any support about the effect of financial stability on firm financing. However, the joint impact of competition and stability suggests that a higher degree of competition and financially stable banking industry can promote formal credit access. The gender gap appears to have played a crucial role in obtaining finance as fewer female participation, and female managers find it difficult to raise credit from the banking markets.

The findings of the study suggest the following policy implications. First, the banking industry in the SSA region, in general, should pursue pro-competitive banking policies. Higher bank competition by lowering interest rate margins can significantly improve access to finance. Second, government stakeholders should pay due attention to reduce the gender gap from every sphere of the region and ensure greater participation of women in business enterprises. Financial policies should be designed in such a way that it encourages women in the model financial markets. Third, policymakers need to ensure that competitive banking operates in a stable financial system.

\section{Declarations}

\section{Availability of data and materials}

We use the data from World Bank Enterprise Survey (https://www.enterprisesurveys.org) and World Bank, Global Financial Database (https://www.worldbank.org/en/publication/gfdr/data/global-financialdevelopment-database). The dataset used in this study is available upon request from the author. 


\section{Competing interests}

The author declares no competing interest exists

\section{Funding}

The author receives no funding to complete this study

\section{Author's contributions}

This paper is written by a single author.

\section{Acknowledgements}

Not applicable

\section{References}

Aluko OA, Ajayi MA (2018). Determinants of banking sector development: Evidence from Sub-Saharan African countries. Borsa Istanbul Review, 18(2), 122-139.

Aterido R, Beck T, \& lacovone L (2013). Access to finance in Sub-Saharan Africa: is there a gender gap?. World development, 47, 102-120.

Berger AN, Klapper LF, Turk-Ariss R(2017). Bank competition and financial stability. In Handbook of Competition in Banking and Finance. Edward Elgar Publishing.

Besanko D,Thakor AV (1992). Banking deregulation: Allocational consequences of relaxing entry barriers. Journal of Banking \& Finance, 16(5), 909-932.

Boone J (2008). A new way to measure competition. The Economic Journal, 118(531), 1245-1261.

Cherif R, Dhungana S, Fang X, Gonzalez-Garcia J, Mendes M, Yang Y, Eun Yoon J(2020). Competition, Competitiveness and Growth in Sub-Saharan Africa.

Čihák M, Hesse H (2010). Islamic banks and financial stability: An empirical analysis. Journal of Financial Services Research, 38(2-3), 95-113.

De Loecker J, Eeckhout J, Unger G (2020). The rise of market power and the macroeconomic implications. The Quarterly Journal of Economics, 135(2), 561-644.

Demirgüç-Kunt A, Honohan P, Beck T (2008). Finance for all?: Policies and Pitfalls in Expanding Access. World bank.

Diez F, Duval R, ChenW, Jones C, Villegas-Sanchez (2019). The rise of corporate market power and its macroeconomic effects. IMF World Economic Outlook. 
Honohan P, Beck T (2007). Making finance work for Africa. The World Bank.

Leon $\mathrm{F}$ (2015). Does bank competition alleviate credit constraints in developing countries?. Journal of Banking \& Finance, 57, 130-142.

Lerner A P (1934). Economic theory and socialist economy. The Review of Economic Studies, 2(1), 51-61.

Mlachila M, Dykes D, Zajc S, Aithnard PH, Beck T, Ncube M, Nelvin O (2013). Banking in sub-Saharan Africa: Challenges and opportunities. Regional Studies and Roundtables.

Otchere I, Senbet L, Simbanegavi W (2017). Financial sector development in Africa-an overview. Review of development finance, 7(1), 1-5.

Petersen MA, Rajan RG (1995). The effect of credit market competition on lending relationships. The Quarterly Journal of Economics, 110(2), 407-443.

Sarpong-Kumankoma E, AborJ Y, Aboagye AQ, Amidu M (2020). Economic freedom, competition and bank stability in Sub-Saharan Africa. International Journal of Productivity and Performance

Management.

\section{Supplementary Files}

This is a list of supplementary files associated with this preprint. Click to download.

- AppendixA.docx 